\title{
Locating a Transnational Film between Korean Cinema and American Cinema: A Case Study of Snowpiercer (2014) Ye Dam Yi
}

This article argues that Joon-ho Bong's Snowpiercer (2013) is a transnational film. It identifies how categorizing it as either Korean cinema or American cinema falls short of accounting for its unprecedented mode of production, distribution, and storytelling. This is a case study that compensates for the existing literature on the movie that often omits its significance in Korean cinema, neglects the ongoing discourse on transnational cinema, and dismisses the filmic text as having nothing to do with the idea of the nation. This study situates Snowpiercer in the larger context of Korean cinema by identifying the heritage it belongs to, shows that the filmic text embodies the complex notion of nation in today's world, and argues that cultural signs in the film indicate a transnational imaginary. The results contribute to identifying how national cinema is changing in relation to increasing transnational film productions and theorizing what the transnational may be for a useful framework.

Keywords: transnational cinema, Snowpiercer, Korean cinema, Hollywood, Joon-ho Bong

An American protagonist leads a revolt after seventeen years of being confined to ghettos in the tail section of a train that carries the humanity around the world after a human effort to fight back global warming results in a catastrophic ice age. A multi-ethnic group joins the revolt against the American conglomerate ruling the passengers in the train section who boarded without a ticket with militant rule. This sounds like a typical dystopian American movie, more so given that the cast is mostly composed of Hollywood actors such as Chris Evans, Tilda Swinton, and John Hurt. But some faces do not seem so American. Two Korean actors play a central role in the movie without speaking English. Kang-ho Song and Ah-sung Go look out of place in the midst of a science fiction (SF) film. A little more investigating reveals that it is not just the presence of these two characters that seems out of place in the movie but the entire plot and production crew. The film is not helmed by an American director but by a Korean one who is known for Memories of Murder (2003) and The Host (2008) that became box office hits in the domestic market. It is also financed by 
CJ Entertainment, one of the biggest entertainment companies in Korea. Given this information, what is uncommon is the very traits that make this film an apparently American movie. An SF film that is rarely produced and embraced in Korea, Snowpiercer is too much Hollywood. Then how should we make sense of this apparent anomaly in both Korean and American cinemas?

Cross-border films have become the focus of debate among film scholars. Higson (2002) has pointed out the limits of a national cinema framework that focuses on the production of a film at the cost of ignoring its international distribution. While Higson called for a way to define national cinema, other scholars seriously engaged with questioning the limits the framework imposes in an era where film productions are becoming increasingly global. These discussions were also largely influenced by studies on transnationalism in the other social sciences that sought to examine today's increasingly prevalent cross-border phenomena such as diaspora. As a result, what is known as transnational cinema has come to be a larger issue. What transnational cinema studies means, however, is not so clearcut. In order to provide a viable framework to work with, Will Higbee and Song Hwee Lim (2010) proposed three major approaches: the transnational as the binary opposite of the national, as a pan-regional culture, and as diasporic/exilic cinema. Chris Berry (2016) followed suit, identifying the transnational as a praxis that arises out of the ideology of globalization yet still retaining a room to fire back at it.

While Snowpiercer can easily fit into the discourse of transnational cinema studies, it has been neglected in the scholarly discourses in Korea. Some criticisms of Snowpiercer focus exclusively on the narrative being a criticism of capitalism without analyzing the film's significance in relation to Korean cinema or to Hollywood (Cho, 2014; Choi, 2015; Kang, 2014). Others deal with how the film can be understood through a transnational framework but either what they mean by transnational is not defined in relation to the ongoing critical discourse or they confine their analysis to production and distribution (Bechervaise, 2017; Han, 2016; N. Kim, 2013; Taylor, 2016).

This limited discourse arises, I believe, due to the unique nature of transnational cinema studies whose relation to national cinema is still much debated on. Another reason is that it is difficult to understand Snowpiercer in relation to Korean cinema; it is easier to classify it as a transnational movie severed from its heritage. But a closer analysis tells us otherwise. The cultural imaginary embedded in the movie allows us an insight into Bong's changing filmography as well as the film industry itself. Aware of both the contributions and the limits of the literature, I intend to locate 
the movie in the larger context of transnational film studies and Korean cinema. This involves analyzing the film in terms of its production and text. This case study contributes to configuring the theoretical problem of what transnational cinema may be. That is, the purpose of this film study is to show in what ways Snowpiercer is a transnational film for film critics both in and out of Korea, the transnational defined as a cultural and material mode that goes beyond and remodels what the national is.

\section{An Anomaly in Korean Cinema}

Bong's Snowpiercer is a science fiction genre film. Bong calls it an "intense SF genre film" (S. Kim, 2013), and his own straightforward definition helps us veer away from political and theoretical interpretations of the film that abound. Bong himself acknowledges the numerous interpretations while inviting us to enjoy the film as it is.

The film is based on the French graphic novel Le Transperceneige (Lob \& Rochette, 1982), a story about the last survivors of humanity on an everrunning train after an attempt to cope with global warming fails and brings about an ice age. While the novel is heavily concerned with environmental issues, the film, originally written by Bong, focuses on the social system in the train largely defined by economic and racial stratification. While those who purchased a train ticket enjoy luxury in the front section, those who boarded without one are lumped together in the tail section and subjected to military rule. The movie follows the advancement of a leader-figure, Curtis Everett, from the tail section to the front, where the mythicized inventor of the ever-running engine, Wilford, resides. Snowpiercer (2013) belongs to what Bong calls the SF films that "simplify and thus dramatize how we live" (J. Lee, 2013, para. 14). That is, the movie is not a SF film mainly characterized by the spectacles of "laser guns" (Laser-guns here works as a metonymy to refer to the kind of science fiction action movies that feature technological innovations as a means to create spectacular action scenes) (Jang, 2013). Rather, it is in line with those films that "portray the grim reality with the special effects intended to highlight certain ... features of the very reality" (para. 11), such as one of Bong's favorite SF films, John Carpenter's The Thing (1982).

Snowpiercer is easily seen as a blockbuster film. Julia Stringer (2003) defined a blockbuster films as "large-scale productions" and "largescale box-office hits" (p. 47). While a blockbuster was initially defined by audience reception, it gradually came to mean high-budget production aiming for big hits. Stringer specified the parameters of what a large-scale production is: the running time, the size of a film's cast, pre-advertisement, and wide release. Given this set of criteria, Snowpiercer is a good example 
of a blockbuster film as it amassed the biggest production budget ever in Korea's film industry-equivalent to $\$ 39,200,000$. It also stars famous Hollywood actors such as Chris Evans, Tilda Swinton, John Hurt, Ed Harris, Octavia Spencer, and Jamie Bell along with two Korean actors, Kang-ho Song, and Ah-sung Ko. This ambitious cast is accompanied by massive domestic marketing carried out by the conglomerate that financed the film, CJ Entertainment. The marketing includes a promotion event that gathered 3,000 Koreans for a virtual experience of the train, complete with a passport, Wilford brochure, and a ticket. Another event distributed fake tickets and fake protein bars featured in the film. Heavy promotion was assisted by a wide release in the domestic market-the sixth largest release ever in Korea. Snowpiercer was shown on 848 screens on opening day alone, later increased to 1,128 . Outside Korea, it was distributed in 167 countries, with The Weinstein Company in charge of distribution in English-speaking countries, and Wildside, a French distributor, in charge of distribution in France, Eastern Europe, and South America.

While the production and distribution model easily makes it a blockbuster movie, it is difficult to position Snowpiercer in the heritage of Korean blockbusters, and, needless to say, in that of Hollywood blockbusters. Since the-first-of-its-kind Shiri (1999), Korean cinema has proven its capability to produce a blockbuster film, previously the exclusive domain of Hollywood moviemakers, characterized by "the foregrounding of spectacle, cultural prestige (or its absence), big budget and big box-office returns, special effects, intertextual commodification, contemporary resonance, and historical endurance" (Shin \& Stringer, 2007, p. 58). Before the 1990s, Korea's film industry was dominated by imported movies, but Shiri (Byeon, Lee \& Kang, 1999) changed the scene. Equipped with Hollywood conventions including a tighter narrative, special effects, spectacle, and romance, this movie told a complex story of a couple caught up in the historical aftermath of North-South Korean relationship and recorded greater box office returns than Titanic (1997), which was released around the same time. Korean blockbuster films that followed also used Hollywood conventions, with emphasis on character development and emotional appeal, in portraying a Korean reality.

Choi (2010) identified three elements of Korean blockbusters distinct from Hollywood films: a relatively smaller production cost, a distribution limited to the domestic market, and a nationalist theme. In particular, the historical relationship between North and South Korea is a recurring theme among successful blockbuster films that came to define the Korean national cinema since Shiri, such as Joint Security Area (2000), Silmido (2003), and Taegukgi (2004). Choi (2010) explained that history is a useful source of 
blockbuster films because it provides a narrative pregnant with plausible action fighting scenes and a story attractive to a "multigenerational audience," and nationalism fueled by the film industry's rivalry with Hollywood counterparts. Sung Kyung Kim (as cited by Choi, 2010) suggested that these blockbusters not only thematize Korean history but also serve as accurate representations of it so that it has come to represent Korea's national cinema (J. Choi, 2010).

Snowpiercer (Bong, 2014) deviates from this heritage. First and foremost, it is a dystopian SF film. Domestic SF films have been notoriously unpopular in Korea, and almost none of the successful blockbuster films belong to the genre. Also, the movie seems to have nothing to do with the nation itself. It not only excludes Korean history from its themes but also does away with the idea of nation itself as the story unfolds in a universal train. In addition, 80 percent of the language spoken is English, with Hollywood and foreign actors dominating the cast, with the exception of the two Korean actors. Moreover, the movie differs from those internationally produced movies that involve production teams from different countries and are shot in either Chinese or Korean.

The movie also deviates from Bong's earlier movies that explored Korean issues. Bong's iconic attachment to Korean landscape, made familiar to the audience in Memories of Murder (2003) and The Host (2008) is gone in Snowpiercer (2014). He himself acknowledged that "the story might not appeal so much to the audience as it does not take place in what's familiar to the Korean audience, but I tried to make the film as interesting as it could be" (H. Choi, 2013, para. 7). In addition, Bong's concern with local issues also seems to be absent. Klein (2008) explained that Bong has always been concerned with Korea's modernity in his films and that he uses Hollywood conventions of the crime genre that uses a surface to crime to probe a deep crime. A murder in Memories of Murder maps the political, economic, and social problems in 1980s Korea. Likewise a monster's attack in The Host reveals Korea's ambivalent relationship with the United States. But this indepth probing into the Korean society is made unnecessary in Snowpiercer in the face of a global disaster that wipes out all geographical and political distinctions among nations and creates a universal caste system on the train.

Snowpiercer (2014) requires an approach that can make sense of its peculiar position in Bong's oeuvre, in Korean cinema, and possibly in global cinema-a transnational framework. While it is a Korean movie, its impact cannot be discussed without its relation to Hollywood films. It uses Hollywood conventions, stars Hollywood actors, and is narrated in English. Understanding why it should be understood as a transnational movie 
demands an explanation on the limits of national cinema and comparative film studies. Higson (2002), famous for his criticism of national cinema, has argued that national cinemas should be defined not only in terms of films produced in a nation-state but also in terms of audience reception given the increasingly international circulation of films (Crofts, 2009). This criticism of the national cinema has sparked an academic interest in alternative ways to approach films. Berry (2016), for example, helped theorize what the transnational means by distinguishing it from the international and globalization. He claimed that the transnational differs from the international in that the former describes individual, corporate-based cross-border coproduction and exchanges while the latter designates more official, nation-to-nation relationships. He also distinguishes the transnational from globalization in that the former is a practice based on the ideology of globalization, such as capitalism and neoliberalism, but which may not be subjected to that very ideology. I would like to use Berry's approach to the transnational since it helps uncover the grey area between what is Korean and what is Hollywood in Snowpiercer as well as identify elements that help us understand how a commercial movie like Snowpiercer may hold some critical significance in examining the current state of globalization.

\section{Identifying the National}

Indeed, Bong (2014) thematizes the inadequacy of the national as a framework in the narrative. The inhabitants of the train are composed of all nationalities, or rather, ethnicities. Displaced from their lands, all ride on the train. There are no national borders, no government institutions, no cultural heritage that binds them together, except for strictly enforced economic hierarchy and racial stratification easily inferred from the composition of those in the tail section and those in the front section. This element in the narrative has compelled Korean critics to identify the universality of the condition as the key to understanding the movie. Indeed, some focus on identifying and criticizing the economic and social system in the movie $(\mathrm{H}$. Cho, 2014; Y. Choi, 2015; Park \& Yoon, 2015). Others read the narrative as an attempt to shed the local in favor of a universal, and thus it carries a transnational appeal (Berchevaise, 2017; Han, 2016; Taylor, 2016). But because the production is transnational, critics assume that the narrative itself obliterates the nation.

However, the narrative itself is pregnant with displaced hauntings of nationality. The two minority characters, Namgoong Minsoo (played by Kang-ho Song) and Yona (Ah-sung Go), represent what is Korean. The name Namgoong Minsoo is intended to signal Korean identity. The last name "Namgoong" itself is a rarity with its two syllables, instead of just 
one. Bong confessed that he chose "a Korean name hardest for foreigners to pronounce" (Snowpiercer Live Showcase Transcript,2013, para. 13). This emphasis on the exotic nature of the name is highlighted in the scene when Namgoong first gives his name to Curtis, who misunderstands it as just "Nam." Namgoong says his name again, together with some Korean curse words, via an electronic translator, which fails to get his message across to Curtis. This failure dramatizes further Namgoong's difference from the rest.

The actors Kang-ho Song and Ah-sung Go have worked with Bong in The Host (2008) and their presence in the shooting site seems to have assured Bong of his sense of identity as a Korean director. In an interview he said:

When I was struggling with my limited English at the shooting scenes, I felt more at ease whenever I heard the two laugh, which I've gotten used to. It reminded me that Snowpiercer is another movie just like those I made in Korea. (Lee, 2013, para. 20)

Just like what the actors did for Bong, the characters Namgoong and Yona remind the audience that this movie is Korean in a way. In particular, Namgoong's presence in the movie evokes Korea's unresolved relationship with Japan, its colonizer in the first half of the twentieth century. Before Namgoong is liberated from prison, a Japanese regiment assistant to the Minister Mason, Fuyu, is just another authority on the train. But when Namgoong joins Curtis's crew to advance to the front section, Fuyu is no longer a random Japanese authority. He is complicit in the system that makes Namgoong a prisoner. While the two figures do not directly engage with each other throughout the film, the contrast between their positions in the train cannot go unnoticed. It brings to mind the Japanese colonial rule in Korea that lasted from 1910 to 1945, a critical period in the modern history of Korea. In particular, the relationship between Fuyu as the police authority and Namgoong as a runaway prisoner hints at the historical period called Military Police Reign Era (1910-1919) during which the police under Japanese control had every right to carry out the executive, legal, and legislative functions of the Korean government. Thus, while national boundaries may be gone in the narrative, the historical significance attached to a Japanese oppressor and a Korean prisoner remains in the movie.

Namgoong further symbolizes a specific point in Korea's economic and social development. The train built by an American conglomerate, the Wilford Industries, represents a rigid society stratified by economic classes due to capitalism. In this system, Namgoong occupies the middle class by 
virtue of not belonging to the front or the tail section. Bong explains in an interview that Namgoong has previously worked for a Korean company, Kyoung Nam Industry, to which Wilford Industries has outsourced door lock installations (Han, 2013). This aptly signifies how Korea rose to become one of the most economically developed countries in the last half century. After the Korean War, the nation strove to emulate Japan in terms of technological and industrial development. Several development plans along the way established its industrial competitiveness, and many companies and industries took on outsourcing jobs from the United States and Europe. This trend continued until the rising cost of production in Korea made it more lucrative to outsource jobs to China. Korea's development and its position in the world economy are well summarized by Namgoong's own journey in the train.

Nonetheless, such references to Korea's national history are qualified. For example, Yona's ethnicity qualifies her as a mono-ethnic Korean. Bong says that Yona was born between Namgoong as an Inuit woman who led the Revolt of the Seven, went outside the train, and froze to death. Her being half-Korean and half-Inuit is unique, considering the relatively homogeneous composition of families in Korea as compared to that in the United States. This non-traditional representation of Korean identity goes in tandem with the representation of Korean history with displaced dynamics between characters in the movie. Snowpiercer veers away from the sort of rigid, well-defined essence of what Korean identity means in those earlier movies such as Shiri, JSA, and Taegukgi that used the defining element of the national identity and further reinforced it for the audience. Instead, Snowpiercer qualifies what Korean identity means through Yona and even through Namgoong's haunting figure.

This modification of identity is not limited to the Korean characters. It also applies to Hollywood. While he has played Captain America, Chris Evans is asked to "hide his muscles" a bit in order to portray a revolutionary yet emotionally complex figure in Snowpiercer. By downplaying his robust physique, his unresolved emotional issues of guilt and self-hatred born out of his attempt to eat a baby when people in the tail section were starving to death shortly after boarding the train are highlighted. What is notable is that this complex figure is subject to Bong's trademark slapsticks. It is not Namgoong but Curtis who slips on a fish during a gory battle against Wilford's thuggish forces. For those familiar with Bong's films, it is not unusual to watch a police investigator fall into a ridge between rice paddies as in Memories of Murder or to see a horrendous monster slip and fall down during a fretful chase as in The Host. But a Hollywood actor doing the same trick is something else. Evans himself said in an interview that "it really is 
so out of left field" (Daniels, 2015). That Curtis played the move in a movie mainly shot with Hollywood actors makes it a peculiar American movie; the slapstick "varies" what is deemed an American movie.

What is assumed here is that Snowpiercer is both a Korean and an American styled movie. In the United States, it is easily classified as an independent SF movie. While it was promoted as a Korean-styled Hollywood blockbuster in the domestic market, it was distributed through art houses in the United States and then produced as a video-on-demand two weeks after release. In a way, the film represents a new mode of Korean film, and it also stands as a variation of American movies. Thus, Snowpiercer is paving the way for a change in both film industries. In Hollywood, it is grouped with other small-budget SF films that are considered more experimental than the big, commercial movies. In Korea, it is the first Korean film to create a SF blockbuster with Hollywood actors as the main cast.

The narrative captures this ambiguous nature of the film in respective film industries-both American and Korean and yet not quite so. From the beginning, Bong portrays an American critique of the allegorically depicted capitalism within the train. After seventeen years of suffering at the tail section, Curtis advances to the front, leading the revolution with the saintly Gilliam, the brotherly Edgar, Tanya, and Grey with the help from kronole-addict Namgoong and clairvoyant Yona. Communicating with Namgoong through an electronic translator, Curtis gets help in opening a gate to the next section one after another by paying Namgoong with kronole, an inflammable industrial waste that is now used as a drug. They go past thuggish forces, take over the water section, and then go through the narrow bridge right before the engine section where Wilford lives. This movement forward, however, comes to a halt at the front section. Wilford persuades Curtis that what humanity needs is harmony, balance, and strict management of the ecosystem that requires an occasional revolution to keep the population at a certain level. What Curtis thought he had achieved was to sabotage the stratification in the train, but Wilford calls it "a blockbuster production with devilishly unpredictable plot" within the larger system that dictates how living things must persevere on the train (Bong, 2013). This captures our own attempts to criticize neoliberalism. The most radical and fierce criticisms of globalizing influence of neoliberalism fail to do away with the unequal distribution of wealth and dominating power of money. And when he falls down to his knees and cries, Curtis gives in to inheriting Wilford's job.

\section{The Transnational Imaginary}

Bong (2013) favors a transnational subversion of the system. Namgoong 
Minsoo plays a significant role to illustrate this point, as his knowledge of the system becomes the ground for a Foucauldian critique. This character holds crucial information hidden from the rest precisely because of his language. Considered a minor language in the film, taking up only 20 percent of the dialogues, Korean is the medium through which rare insights about life and the conditions on the train are shared. In Korean, Namgoong tells Yona a personal account of the Inuit woman who believed that life was possible outside based on her knowledge of ice and snow against the official history that defines the "Frozen Seven" as ridiculous and arrogant to believe that life was possible outside the Snowpiercer. Only Namgoong and Yona know what the leader believed, against the rest of all the English-speaking figures, including Curtis.

Moreover, Namgoong offers an alternative way out of the system. In the narrow bridge scene right before Curtis enters the engine section, Namgoong suddenly tries to hold back Curtis. After a quarrel, with both exhausted, Curtis tells Namgoong about a horrible trauma seventeen years ago when people tried to eat women and babies out of hunger without any food, about his own attempt to eat Edgar, only suspended by Gilliam's sacrifice of his arm. Right after this emotionally troubling monologue, Namgoong says he does not want to open the gate but the gate. Here, the camera movement dramatizes how radical Namgoong's proposal is. The camera first does a close up shot of his face then suddenly makes a 90-degree shift, following Namgoong's right finger that is pointing at the wall to his right-the gate to outside. This shift in the angle puts on screen what has been off screen all along and thus reveals an alternative way out of the system. Namgoong himself says that for seventeen years they were made to believe the wall was not a wall but in fact it is just a "fucking door" (Bong, 2013). Furthermore, Namgoong reveals what has been left unexplained in the film - three scenes along the way to the front where he discovers something but does not share it. He looks out the window and sees a crashed airplane, observes a snowflake drifting through a hole in the window, and looks out again out the window and smiles with surprise. Only when Curtis rebukes Namgoong for having hallucinations because of his addiction to kronole does Namgoong reveal his observations in Korean: the receding level of snow on the crashed airplane that he checks every year, the nature of the snowflake all ready to melt, and something he refrains from sharing, which is probably a sign of life outside.

Michel Foucault's (1980) idea of subjugated knowledge well illustrates how much significant Namgoong's observations are. Foucault introduced the idea of genealogy as a critical ground against a totalizing science or theory. Genealogy is based on an "insurrection of knowledges" (p. 84), 
that have been left out or ignored in the formation of such a science or theory. These knowledges he calls "subjugated knowledges" (p. 83), which include academic facts left out of the process of systemization of a given theory and also other forms local and disqualified knowledges that do not even count as academic knowledges, such as testimonies by prisoners. Recognizing such knowledges points to the critical flaw of any theory not being complete, that the very process of its formation has been subject to ruptures and missing pieces. While Foucault's (1980) genealogy arose in the context of academic endeavors to form a critical ground against totalizing theories such as Marxism and psychoanalysis in the 1980s, the theoretical framework is useful in detecting a totalizing system and conceiving of ways to expose its fallibility.

Bong (2013) portrays Namgoong's national identity as the very means to carry out the critical thrust against Curtis and Wilford's blindness as his minority stance as a kronole-addict Korean locked up in a prison embodies subjugated knowledges. When Curtis and Namgoong talk in the narrow bridge scene, Curtis narrates his story through a monologue. The monologue as a cinematographic device is borrowed from Jaws and has been characteristic of Bong's films. Curtis's message is emotionally charged. However powerful and important the scene is, though, more weight is given to Namgoong's account that comes right after the monologue. Bong makes use of flashbacks with Namgoong's voiceover, and this rich content overrides Curtis's monologue.

Furthermore, Bong (2013) underscores the power of subjugated knowledges in the character of Yona. In the scene where Curtis rejects to give Yona the last match to blow off the train, Yona uses her clairvoyance to detect something under the tile. She frantically tries to lift it, and Curtis joins her, and they discover that Timmy has been manually laboring in there as part of the engine. What has been off-screen becomes on-screen; what has been hidden from view as disqualified knowledge surfaces to debunk the seemingly seamless system of the train. Wilford admits that while he boasts of the train to be perpetual, its parts are not. It is at this point that Curtis decides to put an end to this train that does not guarantee life but consume it. This he does through Yona. Aside from not being a "pure" Korean, Yona has nothing to do with the nation as she was born on the train. Like Timmy, she is also a train baby, that is, she belongs to the generation that has never had a memory of life on earth, unlike Namgoong and Curtis. In a way, the transnational train generation becomes a representation of the imaginary future free from the system.

The idea of the transnational as going beyond and changing the national identity runs parallel to the changing nature of what a national cinema is. 
A movie like Snowpiercer is a challenge to the American film industry. It is compelled to come up with a marketing and distribution strategy that could work for this peculiar movie that is neither a commercial Hollywood film nor a conventional Korean film. This time, the Weinstein Company opted to distribute the film in a way that fits an experimental film-through eight art houses on the day of its release and with a video-on-demand in such a short time. And this certainly has been recognized as an experimental distribution model in the industry.

Likewise, Korean cinema is being transformed. What has always been recognized as national cinema - the historical or the local blockbusternow has to contend with movies like Snowpiercer that celebrate its global competitiveness and demonstrates a distinctly transnational narrative. The collaboration among a Korean director, Hollywood actors, and a Czech production house sets a new model for film production. Some critics such as Huee-yeong Kim (2013) find that Bong falls short of representing Korean cinema as he is not auteuristic enough as Ki-duk Kim, not Korean enough as Je-gyu Kang of Shiri, not technologically innovative enough as Hyungrae Shim, though they assess him as having the best eye for commercial success. This evaluation, however, does not do Bong justice, considering how difficult it is to define national cinema without acknowledging how Hollywood has already permeated it, as Higson (2002) had already pointed out, and how difficult it is to understand Bong's films in relation to its dynamics with Hollywood. Snowpiercer complicates rather than simplifies this problem with Bong's reputation, which can only be assessed properly by studying the shifting relationship between national and transnational cinema, the two landscapes he is changing. Indeed, Bong's upcoming film, Okja, follows the production model of Snowpiercer. It also casts Hollywood actors such as Tilda Swinton and Lily Collins along with Korean actors and thematizes cross-border economic and cultural exchanges.

Snowpiercer (Bong, 2013) is transnational in that it not only goes beyond national borders but also changes the very conventions attached to national cinema in terms of film production, content, and distribution. Bong recapitulates his vision of the transnational in the last scene. Curtis lets Namgoong and Yona fire the kronole bomb, and both men protect Yona and Timmy from the explosion by sacrificing themselves. Bong imagines the subversion of an entire system by blowing up the train as he wanted to "tell a story about how a given social system collapses and a new age arrives" (Han, 2013, para. 12). As the train was invented by the old generation, it is bound to become extinct along with many others. And thus, only those belonging to the new generation survives: Yona and Timmy. The last image 
of the two stepping out of the smashed train onto the snow and looking at the horizon to find a polar bear living outside is pregnant with a message about what a transnational future would look like.

For Bong (2013), children are the most poignant symbol of all the detrimental effects of any social issue, as they occupy the lowest rung in the social hierarchy. This symbolism stuck with Bong when he produced Memories of Murder that dealt with a murder of a child intricately mapped in the time of 1980s, which was characterized by dictatorship, rapid economic development, and repressed democracy. Bong also has recognized that this symbolism not only applies to Korea but to children across the globe. If the impact of a repressive dictatorship, an impotent bureaucracy, and the country's subservient relationship to the United States has outraged him, more so has the structure of today's global world where capitalism and racism do their greatest harm on children.

So in the last scene of Snowpiercer, Bong (2013) places his transnational vision on a half-Eskimo, half-Korean girl and an African American boy. $\mathrm{He}$ said that "the Anglo-Saxons would have gone extinct, only leaving Asians and Africans" (Han, 2013, para. 12), This transnational imaginary directs the audience's attention on the very categories that exceed the nationethnicity and wealth. However, it also portrays the changing nature of the nation, which is becoming more fragmented with respect to ethnicity and wealth. Bong thus goes beyond current conceptions and shakes the ground of the nation.

\section{Conclusion}

My analysis shows that Snowpiercer occupies a transitional place in Bong's filmography as well as in Korean cinema. Both its production and its narrative involve cultural imaginary that remodels what the national cinema is. Moving away from his clear-cut films such as Memories of Murder and The Host, Bong embraces the transnational conception and production of Snowpiercer, which is reflected on how he displaces the signs of the nation in the narrative. This also helps us identify the ways in which Korean cinema is changing. While some critics devalue him for being a "commercial" director who does not seriously inherit and pass on the essence of Korean cinema, Bong's works show us otherwise. His engagement with Hollywood film conventions and his ability to appeal to a large domestic audience attest to the nature of national cinema that Higson identified decades ago. Hollywood has become an indispensable part of national cinema, evident in the success of Shiri and other blockbuster movies after it. Indeed, Bong inherits the heritage. And his successes attest to increasing interest in transnational projects. 
Snowpiercer affects not only Korean cinema but American cinema as well. On the one hand, the narrative itself uses Hollywood conventions in an idiosyncratic way. On the other hand, it has changed how movies produced by Korean directors are received in America's film industry. Instead of being categorized as just another Korean movie, it is considered an independent SF film. In a way, the national identity attached to Korean films has been negotiated in the complex economic cross-border exchanges of the movie. What matters now is not really who directed and produced the movie but how big the production cost was and how commercial it became against the standardized Hollywood conventions. Its distribution model has also become an experimental model in Hollywood where profit is less dependent on box office hits than in Korea.

The dynamics that Snowpiercer creates in relation to Korean and American film industries shows that a transnational film cannot be configured independent of national cinema. It is transnational to the extent that it changes how we think about the national cinema while acknowledging that such a film demands an approach that caters to certain distinctions in the national cinema. The transnational takes the liminal space between the national cinemas and simultaneously exerts its influence on them. 


\section{References}

Bechervaise, J. (2017). Bong Joon-ho and the Korean film industry: The national and transnational cinema intersection (Unpublished doctoral dissertation). Hanyang University.

Berry, C. (2016).What is transnational cinema? Thinking from the Chinese situation. Transnational cinemas, 1(2), 111-127.

Bong, J. (Director). (2013). Snowpiercer [Motion picture]. Korea: CJ Entertainment.

Cho, H. (2014). Snowpiercer: Beyond revolution and reformism. The Magazine of the Korean Society of Civil Engineers, 62(5), 122-125.

Choi, H. (2013, July 24). Snowpiercer: A point-blank commentary on human nature. Retrieved from http:// himentor.co.kr/home/index.php?viewform=eboard\&formpath=\&mode=view\&scatcode=276\&no $=504970 \&$ next $=290^{\circ}$ ode $=0 \&$ mcate $=1 \&$ srch_kind $=\&$ srch_skind $=\&$ srch_word $=$.

Choi, H. (2015, July 30). Where does Assassination rank in terms of production cost?. Retrieved from http:// news.sbs.co.kr/news/endPage.do?news_id=N1003098104.

Choi, J. (2010). The South Korean film renaissance: Local hitmakers, global provocateurs. Middletown, Conn: Wesleyan University Press. Retrieved from http://web.b.ebscohost.com/ehost/ebookviewer/ ebook/ZTAwMHh3d19fMzY2NjEwX19BTg2?sid=07b80cd1-c639-4811-ade9-0c0b66f708c7@ sessionmgr $120 \&$ vid $=0 \&$ format $=$ EK\&lpid $=$ ch $2 \&$ rid $=0$.

Choi, Y. (2015). Snowpiercer's technology, rule system and ethical, emancipatory vision. Han'guk Minjok Munhwa, 54, 271-309.

Crofts, S. (2009). Concepts of national cinema. In J. Hill, P. C. Gibson, R. Dyer, E. A. Kaplan, \& P. Willemen (Eds.), World cinema: critical approaches (pp. 385-394). Oxford: Oxford University Press.

Daniels, H. (2015, February 09). Comic-Con:Chris Evans and Co-Producer Dooho Choi Talk SNOWPIERCER, Elaborate Fight Scenes, the Distribution Model, and More. Retrieved from http://collider.com/chrisevans-snowpiercer-interview/.

Foucault, M. (1980). Two lectures. In C. Gordon (Ed.), Power/knowledge: selected interviews and other writings 1972-1977. New York:Vintage Books.

Han, M. (2016).Transnational cinema and competing universalities : Based on Snowpiercer. FILM STUDIES, $68,255-286$.

Higbee W., \& Lim S.H. (2010). Concepts of transnational cinema:towards a critical transnationalism in film studies. Transnational Cinemas, 1(1), 7-21.

Higson, A. (2002). The European Cinema Reader (pp. 132-142) (C. Fowler, Ed.). London: Routledge.

Jang, B. (2013, July 31). Interview with Bong: Guides for passengers aboard Snowpiercer. Retrieved from http://isplus.live.joins.com/news/article/article.asp?total_id=12215670\&ref=mobile.

Kang, S. R. (2014). Is the class struggle too disturbing in Snowpiercer?.Platform of Criticism_Movie, 41, 5861.

Kim, H. (2013, August 26). Snowpiercer, An Expensive Failure. Retrieved from http://www.mediawatch.kr/ news/article.html?no=242157.

Kim, N. (2013). Changes in Korean film production: A case study of Snowpiercer. Film \& Image Culture, 15, 21-38.

Kim, S. (2013, July 29). Joon-ho Bong, Snowpiercer, an intense SF film. Retrieved from http://tvreport.co.k $r / ? c=$ news\&amp;m=newsview\&amp;idx=375773. 
Klein, C. (2008). Why American Studies Needs to Think about Korean Cinema, or, Transnational Genres in the Films of Bong Joon-ho. American Quarterly, 60(4), 871-898.

Lee, J. (2013, August 1). [Bong Joon-ho says he wanted to "debunk the coarse reality of our social system." Retrieved from http://www.nocutnews.co.kr/news/ 1078202\#csidx6b59573983c564aa80384e8ffe 25930.

Park, S., \& Yoon, A. (2015). Within or beyond governmentality?: Neoliberal governmentality. Snowpiercer. The Journal of Foreign Studies, 32, 227-248.

Stringer, J. (Ed.). (2003). Movie blockbusters. New York: Routledge.

Stringer, J. \& Shin, C. (2007). Storming the Big Screen: The Shiri Syndrome. In F. K. Gateward (Ed.), Seoul searching culture and identity in contemporary Korean cinema (pp. 55-72). Albany: State University of New York Press.

Taylor, B.(2016).The ideological train to globalization:Bong Joon-ho's The Host and Snowpiercer.Cineaction, 98,44-48.

YE DAM YI obtained her master's degree in English Language and Literature from Yonsei University in 2016. Her main interests include film studies, 20th century American literature, and narrative (corresponding author: leonayi818@gmail.com). 